\title{
Corrrigendum: Ganoderma lucidum reduces obesity in mice by modulating the composition of the gut microbiota
}

Chih-Jung Chang, Chuan-Sheng Lin, Chia-Chen Lu, Jan Martel, Yun-Fei Ko, David M. Ojcius, Shun-Fu Tseng, Tsung-Ru Wu, Yi-Yuan Margaret Chen, John D. Young \& Hsin-Chih Lai

Nature Communications 6:7489 doi: 10.1038/ncomms8489 (2015); Published 23 Jun 2015; Updated 11 Jul 2017

The image in Fig. 1e of this Article showing the 'HFD $+8 \%$ ' group was inadvertently duplicated from the 'Chow $+8 \%$ ' group. The correct version of the figure appears below.

(c) Open Access This article is licensed under a Creative Commons Attribution 4.0 International License, which permits use, sharing, adaptation, distribution and reproduction in any medium or format, as long as you give appropriate credit to the original author(s) and the source, provide a link to the Creative Commons license, and indicate if changes were made. The images or other third party material in this article are included in the article's Creative Commons license, unless indicated otherwise in

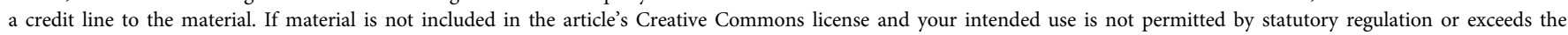
permitted use, you will need to obtain permission directly from the copyright holder. To view a copy of this license, visit http://creativecommons.org/licenses/by/4.0/

(C) The Author(s) 2017 
a

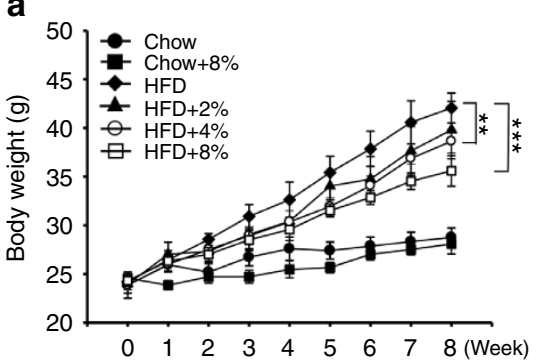

C

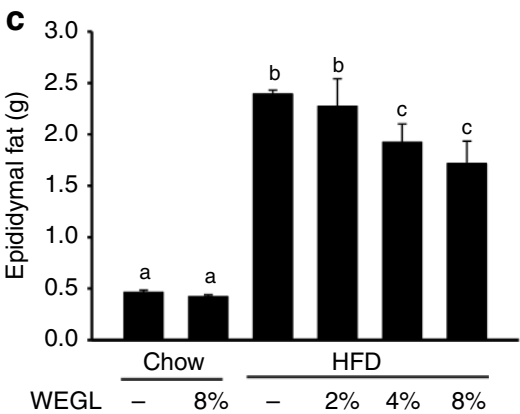

e
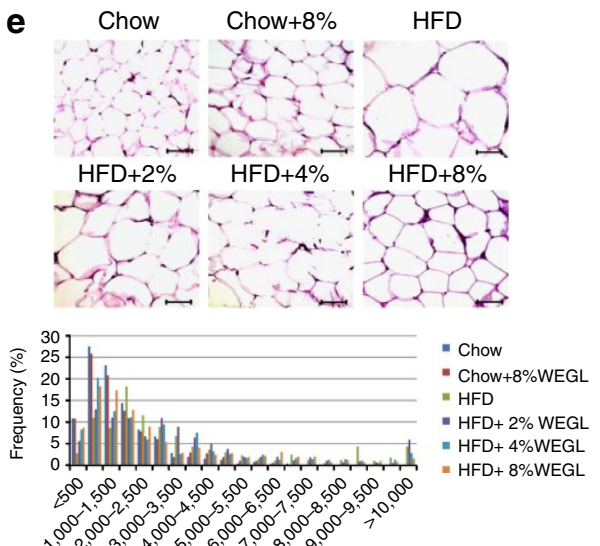

Cell size $\left(\mu \mathrm{m}^{2}\right)$

g

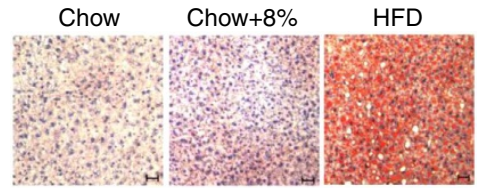

$\mathrm{HFD}+2 \% \quad \mathrm{HFD}+4 \% \quad \mathrm{HFD}+8 \%$

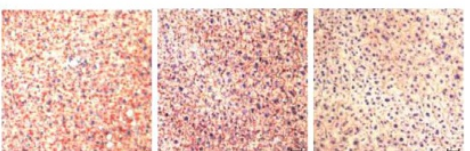

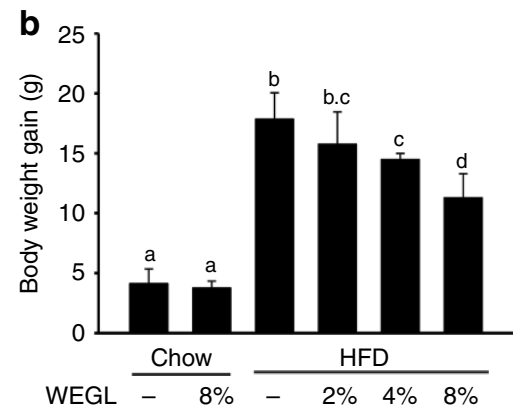
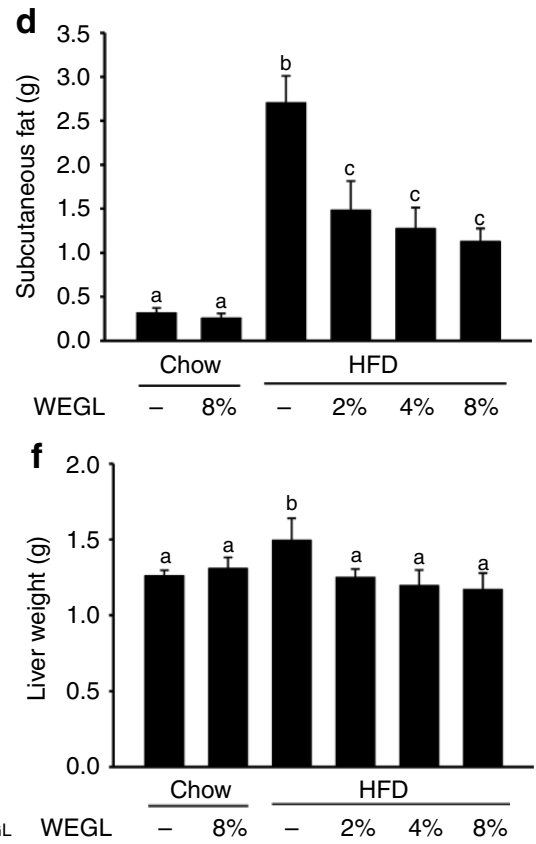

WEGL 